\title{
EFEKTIVITAS MODEL CIRCUIT LEARNING BERBANTU MEDIA DIORAMA MEMPENGARUHI MOTIVASI DAN HASIL BELAJAR PESERTA DIDIK KELAS V
}

\author{
Dyah Saraswati $^{1}$, Sumarno ${ }^{2}$, Anggun Dwi S.P ${ }^{3}$ \\ ${ }^{1}$ Fakultas Ilmu Pendidikan, Universitas PGRI Semarang \\ 1email: dyahsaraswati14@gmail.com
}

\begin{abstract}
This research aimed to determine the effectiveness of circuit learning model assisted by diorama media for influencing the motivation and learning outcomes of class $V$ on theme 7 at SDN Mangunharjo. This research used PreExperimental design, One Group Pretest-Posttest Design. The population of all class $V$ students in SDN Mangunharjo numbered 35 by using nonprobality sampling techniques with saturated sampling types. The average score of pretest motivation was 60.17 and the posttest average was 80.53. The average value of the pretest of the results of learning outcomes is 57.94 and the posttest averages 84.34. This is evidenced by the results of the motivation t-test where $t_{\text {count }}$ (14.31)> $t_{\text {table }}$ (1.69). Calculation of t-test results of learning where $t_{\text {count }}$ (13.28)> $t_{\text {table }}(1.69)$. This is also supported by $N$-Gain motivation and learning outcomes that show criteria of moderate to high. The concluded that the circuit learning model assisted by diorama media effectively influences the motivation and learning outcomes of the fifth grade students of Mangunharjo Elementary School Semarang.
\end{abstract}

Keywords: learning motivation, learning outcomes, circuit learning models

\begin{abstract}
Abstrak
Penelitian ini bertujuan untuk mengetahui efektivitas model circuit learning berbantu media diorama untuk mempengaruhi motivasi dan hasil belajar peserta didik kelas V tema 7 di SDN Mangunharjo. Penelitian ini menggunakan PreEksperimental design yaitu One Group Pretest-Posttest Design. Populasi semua peserta didik kelas V di SDN Mangunharjo berjumlah 35 dengan menggunakan teknik sampling nonprobality sampling dengan jenis sampling jenuh. Nilai ratarata motivasi pretest 60,17 dan rata-rata posttest 80,53 . Nilai rata-rata pretest hasil hasil belajar 57,94 dan posttest rata-rata 84,34. Hal tersebut dibuktikan dengan hasil uji-t motivasi dimana $t_{\text {hitung }}(14,31)>t_{\text {tabel }}(1,69)$. Perhitungan uji- $t$ hasil belajar dimana $t_{\text {hitung }}(13,28)>t_{\text {tabel }}(1,69)$. Hal tersebut juga didukung dengan $N$-Gain motivasi dan hasil belajar yang menunjukkan kriteria sedang hingga tinggi. Dapat disimpulkan bahwa model circuit learning berbantu media diorama efektif mempengaruhi motivasi dan hasil belajar peserta didik kelas $\mathrm{V}$ SDN Mangunharjo Semarang.
\end{abstract}

Kata Kunci : motivasi belajar, hasil belajar, model circuit learning 
PENDAHULUAN

Kurikulum pendidikan di Indonesia sekarang ini menggunakan kurikulum 2013. Kurikulum 2013 memiliki 3 aspek penilaian yaitu aspek pengetahuan atau kognitif, aspek sikap atau afektif dan aspek keterampilan atau psikomotorik. Kurikulum 2013 pada sistem pembelajarannya berpusat pada peserta didik, yang mana peserta didik lebih aktif saat pembelajaran dan guru hanya sebagai fasilitator yaitu guru memberi kemudahan peserta didik untuk melakukan aktivitas belajar. Peserta didik harus bisa menggali informasi dan berfikir kritsis terhadap materi yang sedang dipelajari. Peserta didik harus mempunyai motivasi dalam belajar supaya proses pembelajaran dapat berjalan dengan lancar dan mendapatkan hasil yang maksimal. Menurut Widiasworo (2017:16) menyatakan bahwa motivasi adalah keseluruhan daya penggerak, baik dalam diri maupun dari luar dengan menciptakan serangkaian usaha untuk menyediakan kondisikondisi tertentu yang menjamin kelangsungan dan memberikan arah pada kegiatan sehingga tujuan yang dikehendaki oleh subjek itu dapat tercapai.
Berdasarkan hasil wawancara dengan guru kelas V SDN Mangunharjo Semarang pada hari Senin 24 September 2018, menunjukkan bahwa masih terdapat peserta didik yang mendapatkan nilai dibawah Kriteria Ketuntasan Minimum (KKM) hal tersebut mengindikasi kurangnya motivasi belajar peserta didik karena faktor internal. Faktor internal bisa dilihat dari cara mengajar guru yang kurang menarik dan masih menggunakan model pembelajaran yang konvensional serta media yang kurang inovatif sehingga peserta didik merasa bosan dan motivasi belajar peserta didik akan turun dan mengakibatkan hasil belajar tidak maksimal.

Salah satu upaya yang dapat dilakukan untuk meningkatkan motivasi dan hasil belajar peserta didik bisa dilakukan dengan memberikan pembelajaran yang menarik dan menyanangkan misalnya dengan menggunakan model pembelajaran circuit learning dan media diorama saat pembelajaran sehingga tujuan pembelajaran dapat tercapai dengan baik. Model pembelajaran circuit learning dipilih peneliti karena guru masih menggunakan model 
pembelajaran konvensional. Model pembelajaran circuit learning ini diharapkan dapat meningkatkan motivasi dan hasil belajar peserta didik pada pembelajaran tematik kelas $\mathrm{V}$ SDN Mangunharjo Semarang. Selain model pembelajaran, media pembelajaran juga diperlukan dalam proses belajar mengajar. Media pembelajaran harus inovatif supaya peserta didik tidak merasa bosan. Misalnya dengan menggunakan media diorama. Guru kelas V di SDN Mangunharjo belum pernah menggunakan media diorama saat pembelajaran. Diorama menurut Nana Sudjana dan Ahmad Rivai (2002) diorama adalah pemandangan tiga dimensi mini yang bertujuan untuk menggambarkan pemandangannya sebenarnya dan biasanya terdiri atas bentuk-bentuk sosok atau objek-objek yang ditempatkan di pentas yang berlatar lukisan yang disesuaikan dengan penyajian.

Peneliti memilih menggunakan media diorama dalam pembelajaran tematik supaya memudahkan peserta didik dalam memahami materi yang akan disampaikan, selain itu sebelumnya guru belum pernah menggunakan media diorama dalam proses pembelajaran sehingga peneliti menggunakan media ini untuk menarik peserta didik supaya motivasi belajar bertambah.

\section{METODE PENELITIAN}

Pada penelitian ini menggunakan metode penelitian kuantitatif dengan menggunakan metode eksperimental. Desain eksperimental yang digunakan dalam penelitian ini adalah Pre Experimental Design dengan bentuk One Group Pretest-Posttest Design. Sugiyono (2016: 109) menyatakan bahwa dikatakan Pre Experimental Design, karena desain ini belum merupakan eksperimen yang sungguhsungguh. Subjek pada penelitian ini adalah seluruh peserta didik kelas $\mathrm{V}$ SDN Mangunharjo Semarang dengan jumlah 35 peserta didik. Penelitian ini dilaksanakan pada semester genap pada Tahun Pelajaran 2018/2019.

Penelitian ini akan menggunakan teknik pengumpulan data diantaranya yaitu tes, kuesioner (angket), wawancara, observasi, dan dokumentasi.

$$
\text { Pengujian Instrumen yang }
$$
digunakan adalah validitas, reliabilitas taraf kesukaran, dan daya pembeda. Pada kuesioner (angket) motivasi belajar menggunakan rumus alpha untuk mengetahui validitas dan reliabilitas item pertanyaan yaitu sebanyak 52 item 
pertanyaan dan digunakan 30 item pertanyaan. Sedangkan hasil belajar menggunakan rumus K-R 20 untuk mengetahui validitas, reliabilitas, taraf kesukaran, dan daya pembeda butir soal yaitu sebanyak 50 butir soal dan digunakan 25 butir soal.

Teknik analisis digunakan untuk mengolah data hasil penelitian yaitu data motivasi belajar, hasil belajar, hasil wawancara, hasil observasi. Data observasi, dan wawancara dianalisis menggunakan analisis deskriptif sebagai data pendukung. Sedangkan data hasil belajar dan motivasi belajar merupakan data utama yang akan dihitung dari perolehan pretest yaitu sebelum diberi perlakuan dengan menggunakan model circuit learning dan dihitung dari perolehan nilai posttest yaitu setelah diberi perlakuan dengan menggunakan model circuit learning.

\section{HASIL DAN PEMBAHASAN}

Pada penelitian ini menggunakan Pretest dan Posttest. Pretest dan Posttest yang diberikan yaitu berupa angket motivasi belajar pembelajaran tematik dan soal pilihan ganda. Berikut merupakan data hasil penelitian angket motivasi belajar pembelajaran tematik kelas V SD N Mangunharo Semarang.

Tabel 1. Hasil Angket Motivasi Belajar Tematik Kelas V SDN Mangungarjo Semarang

\begin{tabular}{llcl}
\hline Keterangan & \multicolumn{1}{c}{$\begin{array}{c}\text { Skor } \\
\text { Maksimal }\end{array}$} & $\begin{array}{c}\text { Skor } \\
\text { Minimal }\end{array}$ & Rata-rata \\
\hline Pretest & 72 & 49,33 & 60,17 \\
Posttest & 91,33 & 67,33 & 80,53 \\
\hline
\end{tabular}

Sumber: Data Hasil Penelitian 2019

Berdasarkan tabel 1 menunjukkan bahwa hasil sebelum diberi perlakuan menunjukkan bahwa skor maksimal yang didapatkan peserta didik adalah 72 dan skor minimal yang didapatkan peserta didik adalah 49,33 dengan ratarata nilai 60,17 sedangkan pada hasil setelah diberi perlakuam menunjukkan bahwa skor maksimal yang didapatkan peserta didik adalah 91,33 dan skor minimal yang didapatkan peserta didik adalah 67,33 dengan rata-rata nilai 80,53. Maka dapat disimpulkan bahwa hasil angket motivasi belajar pembelajaran tematik pada kelas V SDN Mangunharjo Semarang sebelum dan sesudah diberi perlakuan dengan menggunakan model circuit learning berbantu media diorama mengalami peningkatan.

Tabel 2. Hasil Belajar Peserta Didik Kelas V SDN Mangunharjo Semarang

\begin{tabular}{|c|c|c|c|}
\hline \multirow[t]{2}{*}{ Keterangan } & Skor & Skor & Rata-rata \\
\hline & Maksimal & Minimal & \\
\hline Pretest & 84 & 32 & 57,94 \\
\hline
\end{tabular}




\begin{tabular}{cccc} 
Posttest & 100 & 52 & 81,60 \\
\hline Sumber: & Data Hasil Penelitian & 2019
\end{tabular}

Berdasarkan tabel 2 menunjukkan bahwa hasil pretest menunjukkan bahwa rata-rata nilai sebesar 57,94 dengan nilai maksimal 84 dan nilai minimal 32. Pada hasil posttest sebesar 84,34 dengan nilai maksimal 100 dan nilai minimal 60 . Maka dapat disimpulkan bahwa nilai hasil belajar pada tema tema 7 "peristiwa dalam kehidupan" subtema 1 "peristiwa kebangsaan masa penjajahan" pada pembelajaran 1,2 dan 3 pada kelas $\mathrm{V}$ SDN Mangunharjo Semarang sebelum dan sesudah diberi perlakuan dengan menggunakan model circuit learning berbantu media diorama mengalami peningkatan.

Selanjutnya dari nilai pretest dan posttest motivasi dan hasil belajar dibandingkan dengan uji-t yang bertujuan untuk mengetahui ada atau tidaknya peningkatan motivasi dan hasil belajar dengan menggunakan model circuit learning berbantu media diorama.

Tabel 3. Hasil Uji-t Motivasi Belajar

\begin{tabular}{|c|c|c|c|c|c|c|c|}
\hline \multirow[t]{2}{*}{ Sampel } & \multicolumn{2}{|c|}{ Rata-Rata } & \multirow[t]{2}{*}{$\mathrm{N}$} & \multirow[t]{2}{*}{$t_{\text {hitung }}$} & \multirow[t]{2}{*}{$\mathrm{t}_{\text {tabel }}$} & \multirow[t]{2}{*}{ Kriteria } & \multirow[t]{2}{*}{ Ket } \\
\hline & $\begin{array}{c}\text { Sebelum } \\
\text { diberi } \\
\text { perlakuan }\end{array}$ & $\begin{array}{c}\text { Sesudah } \\
\text { diberi } \\
\text { perlakua } \\
\text { n }\end{array}$ & & & & & \\
\hline $\begin{array}{c}\text { Kelas V } \\
\text { SDN }\end{array}$ & 60,17 & 80,53 & 35 & 14,31 & 1,69 & $\begin{array}{c}\mathrm{t}_{\text {hitung }}> \\
\mathrm{t}_{\text {tabel }}\end{array}$ & $\begin{array}{c}\mathrm{H}_{0} \\
\text { dito }\end{array}$ \\
\hline $\begin{array}{c}\text { Mangharj } \\
\text { o } \\
\text { semarang }\end{array}$ & & & & & & & lak \\
\hline
\end{tabular}

Sumber: Analisis Hasil Penelitian 2019

Berdasarkan tabel 3 menunjukkan bahwa diperoleh rata-rata sebelum diberi perlakuan sebesar 60,17 dan rata-rata sesudah diberi perlakuan sebesar 80,53 dengan $\mathrm{db}=\mathrm{N}-1=35-1=34$ diperoleh $\mathrm{t}_{\text {hitung }} \quad 14,31$ menggunakan taraf signifikan 5\% diperoleh $t_{\text {tabel }} 1,69$. Dapat diketahui bahwa $t_{\text {hitung }}(14,31)>t_{\text {tabel }}$ $(1,69)$ jadi $\mathrm{H}_{0}$ ditolak maka $\mathrm{H}_{\mathrm{a}}$ diterima sehingga pembelajaran model pembelajaran circuit learning berbantu media diorama efektif mempengaruhi motivasi belajar dalam pembelajaran tematik peserta didik kelas V SDN Mangunharjo Semarang.

Tabel 4. Hasil Uji-t Hasil Belajar

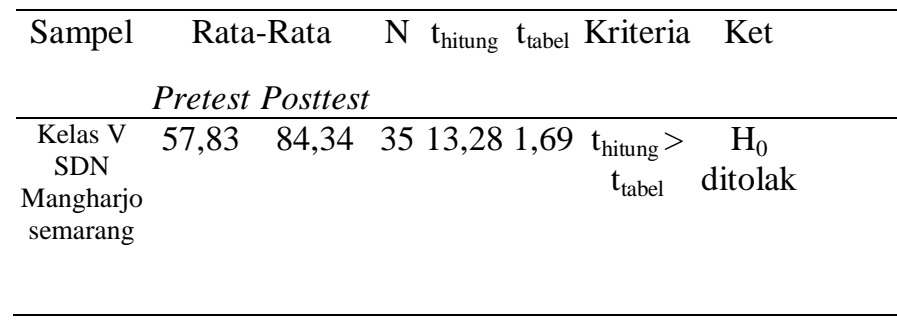

umber: Analisis Hasil Penelitian 2019

Berdasarkan tabel 4 menunjukkan bahwa diperoleh rata-rata pretest sebesar 57,83 dan rata-rata posttest sebesar 84,34 dengan $\mathrm{db}=\mathrm{N}-1=35-1=34$ diperoleh $t_{\text {hitung }} 13,28$ menggunakan taraf signifikan 5\% diperoleh $\mathrm{t}_{\text {tabel }} 1,69$. Dapat diketahui bahwa $t_{\text {hitung }}(11,91)>t_{\text {tabel }}$ $(1,69)$ jadi $\mathrm{H}_{0}$ ditolak maka $\mathrm{H}_{\mathrm{a}}$ sehingga pembelajaran model pembelajaran circuit learning berbantu media diorama efektif mempengaruhi hasil belajar dalam pembelajaran tematik peserta 
Prodi PGSD Universitas Slamet Riyadi

ISSN 2620-6560 (print) ISSN 2620-746X (online)

didik kelas V SDN Mangunharjo Semarang

Tabel 5. Rekapitulasi N-Gain Motivasi Belajar

\begin{tabular}{ccccc}
\hline $\begin{array}{c}\text { Peserta } \\
\text { didik }\end{array}$ & $\begin{array}{c}\text { Rata- } \\
\text { rata }\end{array}$ & $\begin{array}{c}\text { Rata- } \\
\text { rata }\end{array}$ & $\begin{array}{c}\text { gain } \\
\text { motivasi }\end{array}$ & Kriteria \\
& Pretest & Posttest & & \\
\hline 35 & 60,17 & 80,53 & 0,511 & Sedang \\
\hline
\end{tabular}

Sumber: Analisis Hasil Penelitian 2019

Berdasarkan tabel 5 perhitungan motivasi belajar dengan menggunakan Uji N-Gain menunjukkan bahwa nilai rata-rata motivasi belajar peserta didik sebelum diberi perlakuan menggunakan model circuit learning adalah 60,17, sedangkan nilai rata-rata motivasi belajar peserta didik setelah diberi perlakuan dengan menggunakan model circuit learning berbantu media diorama adalah 80,53. Gain keseluruhan motivasi belajar tematik adalah 0,511 dengan kategori sedang.

Tabel 6. Rekapitulasi N-Gain Hasil Belajar

\begin{tabular}{ccccc}
\hline Peserta & Rata- & Rata- & Hasil & Kriteria \\
didik & rata & rata & gain & \\
& Pretest & Posttest & $\begin{array}{c}\text { hasil } \\
\text { belajar }\end{array}$ & \\
& & & 0,630 & Sedang \\
\hline 35 & 57,83 & 84,34 & 0 &
\end{tabular}

Sumber: Analisis Hasil Penelitian 2019

Berdasarkan tabel 6 perhitungan hasil belajar dengan menggunakan Uji $\mathrm{N}$-Gain menunjukkan bahwa nilai ratarata motivasi belajar peserta didik sebelum diberi perlakuan menggunakan model circuit learning adalah 57,83, sedangkan nilai rata-rata motivasi belajar peserta didik setelah diberi perlakuan dengan menggunakan model circuit learning berbantu media diorama adalah 84,34. Gain keseluruhan motivasi belajar tematik adalah 0,630 dengan kategori sedang.

Model pembelajaran circuit learning berbantu media diorama efektif mempengaruhi motivasi dan hasil belajar peserta didik kelas V SDN Mangunharjo Semarang. Model pembelajaran circuit learning adalah model pembelajaran yang dapat meningkatkan pengetahuan peserta didik dengan memaksimalkan pikiran dengan pola bertambah dan mengulang sehingga memaksimalkan pemberdayaan pikiran peserta didik dan peserta didik akan lebih mudah dalam memahami materi yang disampaikan guru. Penelitian ini sesuai dengan penelitian Hakim (2015) bahwa dengan menggunakan model circuit learning dapat meningkatkan hasil belajar, bahkan dengan menggunakan model circuit learning hasil belajarnya lebih baik dari menggunakan model konvensional. 
Penggunaan media diorama dalam model circuit learning direspon secara positif oleh peserta didik. Peserta didik antusias dengan media diorama yang digunakan peneliti, peserta didik dapat memegang dan memainkan secara langsung media diorama tersebut sehingga peserta didik tidak merasa bosan dan jenuh saat proses pembelajaran dibandingkan dengan tidak menggunakan media. Penelitian ini didukung oleh penelitian Sholikhah (2016) yang didalam penelitiannya terdapat ahli yang berpendapat bahwa kelebihan diorama adalah mempermudah peserta didik dalam belajar, membantu pendidik dalam memberikan penjelasan tentang suatu objek atau benda yang rumit atau asing bagi peserta didik. Sehingga media diorama efektif meningkatkan motivasi belajar peserta didik.

Motivasi belajar peserta didik meningkat secara signifikan. Dibuktikan dengan hasil rata-rata pretest sebesar 60,17 dan rata-rata posttest sebesar 80,53 dengan $\mathrm{db}=\mathrm{N}-1=35-1=34$ diperoleh $\mathrm{t}_{\text {hitung }} \quad 14,31$ menggunakan taraf signifikan 5\% diperoleh $\mathrm{t}_{\text {tabel }}$ 1,69. Dapat diketahui bahwa $\mathrm{t}_{\text {hitung }}(14,31)>\mathrm{t}_{\text {tabel }}$ $(1,69)$. Maka model circuit learning berbantu media diorama efektif mempengaruhi motivasi dan hasil belajar peserta didik. Penelitian ini sesuai dengan penelitian Effendi (2017) bahwa hasil belajar mengalami peningkatan yang signifikan yaitu nilai rata-rata pretest 42,92 dan rata-rata posttest sebesar 67,69. Dengan uji hipotesis diperoleh nilai $t_{\text {hitung }}(14,05)>t_{\text {tabel }}$ $(1,691)$. Jadi hasil belajar meningkat secara signifikan.

Peningkatan motivasi belajar juga dihitung dengan menggunakan Uji NGain menunjukkan motivasi belajar peserta didik sebelum diberi perlakuan dan sesudah diberi perlakuan dengan menggunakan uji N-Gain adalah ada 3 (tiga) kategori yaitu rendah, sedang, dan tinggi. Peserta didik yang memiliki kategori rendah ada 5 orang, peserta didik yang memiliki kategori sedang ada 27 orang, dan peserta didik yang memiliki kategori tinggi ada 3 orang. Penelitian ini sesuai dengan penelitian Jumiat, dkk (2011) bahwa peningkatan hasil belajar dapat dilihat dari rerata $\mathrm{N}$ Gain pada kelas eksperimen 0,53 dengan kategori sedang dan pada kelas kontrol 0,42 dengan kategori sedang. Pada kelas kontrol dan kelas eksperimen memiliki hasil belajar yang signifikan.

Peningkatan motivasi belajar berimpilikasi pada hasil belajar peserta 


\section{Jurnal Sinektik}

Volume 3 Nomor 1, Edisi Juni 2020

Prodi PGSD Universitas Slamet Riyadi

ISSN 2620-6560 (print) ISSN 2620-746X (online)

didik kelas V SDN Mangunharjo

Semarang yang dapat dibuktikan dengan perhitungan hasil belajar dengan menggunakan uji-t menunjukkan bahwa diperoleh rata-rata pretest sebesar 57,83 dan rata-rata posttest sebesar 84,34 dengan $\mathrm{db}=\mathrm{N}-1=35-1=34$ diperoleh $t_{\text {hitung }} \quad 13,28$ menggunakan taraf signifikan 5\% diperoleh $\mathrm{t}_{\text {tabel }}$ 1,69. Dapat diketahui bahwa $t_{\text {hitung }}(13,28)>t_{\text {tabel }}$ $(1,69)$ jadi $\mathrm{H}_{0}$ ditolak maka $\mathrm{H}_{\mathrm{a}}$ sehingga pembelajaran model pembelajaran circuit learning berbantu media diorama efektif mempengaruhi hasil belajar dalam pembelajaran tematik peserta didik kelas V SDN Mangunharjo Semarang.

Perhitungan hasil belajar dengan menggunakan Uji N-Gain menunjukkan hasil belajar pretest dan posttest menggunakan uji N-Gain peserta didik adalah ada 3 (tiga) kategori yaitu rendah,sedang, dan tinggi. Peserta didik yang memiliki kategori rendah ada 3 orang, peserta didik yang memiliki kategori sedang ada 21 orang, dan peserta didik yang memiliki kategori tinggi ada 11 orang.

Nilai hasil belajar pembelajaran tematik yang berupa pretest yaitu tes awal sebelum diberi perlakuan dengan menggunakan model circuit learning berbantu media diorama dengan hasil posttest yaitu tes akhir setelah diberi perlakuan dengan menggunakan model circuit learning berbantu media diorama kelas V SDN Mangunharjo Semarang menunjukkan hasil yang berbeda. Pada hasil pretest menunjukkan bahwa ratarata nilai sebelum adanya perlakuan menggunakan model circuit learning berbantu media diorama adalah 57,83 dengan nilai maksimal 84 dan nilai minimal 32 dan peserta didik yang mencapai batas ketuntasan berjumlah 9 orang sedangkan peserta yang tidak mencapai batas ketuntasan berjumlah 26 orang. Pada hasil posttest menunjukkan bahwa rata-rata nilai sesudah adanya perlakuan menggunakan model circuit learning berbantu media diorama adalah 84,34 dengan nilai maksimal 100 dan nilai minimal 60 dan peserta didik yang mencapai batas ketuntasan berjumlah 31 orang sedangkan peserta yang tidak mencapai batas ketuntasan berjumlah 4 orang. Maka dapat disimpulkan bahwa nilai hasil belajar pada tema tema 7 "peristiwa dalam kehidupan” subtema 1 "peristiwa kebangsaan masa penjajahan" pada pembelajaran 1,2 dan 3 pada kelas V SDN Mangunharjo Semarang sebelum 
dan sesudah diberi perlakuan dengan menggunakan model circuit learning berbantu media diorama mengalami peningkatan.

Hasil observasi pembelajaran pada pertemuan 1,2, dan 3 yang telah dilakukan observer I dan II menunjukkan skor perolehan yang berbeda Observer I dan II memberikan penilaian sesuai dengan apa yang diamati secara langsung pada saat pembelajaran. Sehingga diperoleh skor dan kriteria yang berbeda antara observer I dan observer II ada kriteria cukup baik, baik, dan sangat baik. Peserta didik merespon pembelajaran dengan baik pada saat peneliti menyampaikan pembelajaran dengan menggunakan model circuit learning berbantu media diorama. Peserta didik juga aktif bertanya dan memberikan respon saat peneliti memberikan pertanyaan.

Peningkatan motivasi dan hasil belajar selain dilihat hasil kuesioner, soal pilihan ganda, observasi pembelajaran juga dapat dilihat dari wawancara dilakukan peneliti dengan beberapa peserta didik dengan memberikan 5 pertanyaan dan peserta didik memberi jawaban. Pada setiap pertanyaan yang diajukan peneliti peserta didik memberikan jawaban yang positif mengenai model circuit learning berbantu media diorama yang telah digunakan peneliti. Dengan demikian tujuan peneliti telah tercapai yaitu peneliti telah membuktikan jika dengan menggunakan model pembelajaran circuit learning berbantu media diorama dapat meningkatkan motivasi dan hasil belajar peserta didik kelas V SDN Mangunharjo Semarang. Dengan demikian pada penelitian ini dengan menggunakan model pembelajaran circuit learning berbantu media diorama mempengaruhi motivasi dan hasil belajar peserta didik kelas V SDN Mangunharjo Semarang.

\section{SIMPULAN}

Berdasarkan hasil penelitian dan pembahasan, dapat disimpulkan bahwa model pembelajaran circuit learning berbantu media diorama efektif mempengaruhi motivasi dan hasil belajar peserta didik kelas V SDN Mangunharjo Semarang pada tema 7 "peristiwa dalam kehidupan" subtema 1 "peristiwa kebangsaan masa penjajahan" pembelajaran 1,2.

Hal tersebut dapat dilihat pada hasil kuesioner sesudah menggunakan model circuit learning berbantu diorama lebih baik daripada sebelum 
menggunakan model circuit learning berbantu media diorama. Hasil belajar posttest lebih baik dibandingkan hasil belajar pretest. Faktor yang membuat model pembelajaran circuit learning efektif mempengaruhi motivasi dan hasil belajar karena model circuit learning mampu menciptakan suasana yang menyenangkan dan tidak membuat peserta didik jenuh dengan media diorama dalam proses pembelajaran. Sselain itu juga peserta didik menjadi aktif saat proses pembelajaran berlangsung. Maka media circuit learning berbantu media diorama efektif mempengaruhi motivasi dan hasil belajar peserta didik kelas V SDN Mangunharjo Semarang.

Berdasarkan kesimpulan penelitian ini, dapat diajukan beberapa saran bagi peneliti selanjutnya, diharapkan menggunakan model pembelajaran circuit learning pada saat proses pembelajaran supaya peserta didik tidak bosan dengan pembelajaran yang menggunakan model konvensional dan media diorama dapat digunakan supaya guru lebih mudah menyampaikan materi pembelajaran kepada peserta didik sehingga peserta didik merasa senang dan tidak merasa bosan sehingga motivasi dan hasil belajar peserta didik dapat meningkat.

\section{DAFTAR PUSTAKA.}

Effendi, M. Amrullah. 2017. Pengaruh Model Circuit Learning Terhadap Hasil Belajar Biologi Siswa Pada Materi Sistem Ekskresi di Kelas XI SMA Prayatna Medan. Prosiding Seminar Naional III Biologi dan Pembelajarannya. ISBN 978-6025097-51-4.

Hakim, Arif Rochman. 2015. Pengaruh Model Circuit learning Terghadap Hasil Belajara Siswa Tema Ekosiistem di Sekolah Dasar. JPGSD. Vol 03 No 02.

Jumiati, dkk. 2011. Peningkatan Hasil Belajar Siswa dengan Menggunakan Model Numbereds Heads Together (NHT) Pada Materi Gerak Tumbuhan di Kelas VII SMP Sei Putih Kampar. Lectura. Volume 02 Nomor 02.

Nana Sudjana dan Ahmad Rivai. 2002. Media Pengajaran. Bandung: Sinar Baru Algensindo

Sholikhah, Nikmatus. 2016. Penggunaan Media Diorama untuk Meningkatkan Hasil Belajar Siswa Kelas IV A Tema Tempat Tinggalku di SDN Menur Pumpungan Surabaya. JPGSD Volum 04 Nomor 02.

Sugiyono. 2016. Metode Penelitian Pendidikan Pendekatan Kuantitatif, Kualitatif, dan $R \& D$. Bandung: Alfabeta. 
Widiasworo, Erwin. 2017. 19 Kiat Sukses Membangkitkan Motivasi Belajar Pesrta Didik.

Yogyakarta: Ar-Ruzz Media 
